\title{
Quality Assurance in Education: Readiness of Islamic Higher Education to Face the New Accreditation Model in Indonesia
}

\author{
Musthofa Musthofa ${ }^{1}$, Lulu Choirun Nisa ${ }^{2}$, Yuyun Affandi ${ }^{3}$ \\ Universitas Islam Negeri Walisongo Semarang, Indonesia ${ }^{1,2,3}$ \\ \{thofa@walisongo.ac.id¹, lulu.choirunnisa@walisongo.ac.id², yuyunaffandi@walisongo.ac.id ${ }^{3}$ \}
}

\begin{abstract}
A fundamental change of an accreditation model makes disequilibrium. The paper aims to study the readiness of the Islamic universities in Indonesia to face a new accreditation model. The blended research data through the purposive sampling technique are analyzed quantitatively and qualitatively. This research shows that many State Islamic Religious College (PTKIN) is not ready to face APT 3.0. Only 28.6\% (two out of seven) of PTKIN have excellent internal management and quality assurance system. The lecturer ratio's accreditation score has reached $42.8 \%$ (three out of seven) of PTKIN, but the professors' ratio is still meager, only $2.96 \%$. PTKIN still needs serious work to deal with the new APT model to assess satisfactory results.
\end{abstract}

Keywords: Quality Assurance; Education Accreditation; Management; Human Resources

\section{Introduction}

Higher Education Accreditation (APT) as a means of quality assurance needs renewal and improvement of its achievement criteria; however, many previous accreditation achievements have not met expectations. In Indonesia, there are 58 State Islamic Religious Colleges (PTKIN); only seven of them were accredited A, 41 PTKIN (B), eight PTKIN (C), and two PTKIN had not yet been accredited. Meanwhile, the National Accreditation Board for Higher Education (BAN-PT) has updated the accreditation model known as APT 3.0 in 2017. The changes are quite basic and complex. Among them are: (1) feasibility and achievement of standards, (2) reference to inputs, processes, outputs, and outcomes; (3) there are 24 standards in nine criteria; (4) additional requirements to achieve superior predicate; and (5) improvement of score achievement criteria. The quality and value of accreditation are strongly determined by the organization and the institution's resources so that readiness needs to be studied.

The readiness of a higher education to face accreditation will lead to the achievement of the expected predicate. The principle of compliance with 24 standards in the APT 3.0 scoring system and additional requirements in value limits become the basis of an excellent score. The score of accreditation does not work naturally but requires the best management strategy. This score requires changes and adjustments in implementing education on campus, especially 
management, human resources, and scientific publications. According to Equilibration Theory, efforts to accommodate and assimilate the instrument are the basis adjustment and balancing in the APT. This assimilation and accommodation process will realize the objectives of accreditation as a quality assurance tool and an indicator of the quality of PTKIN. An excellent accredited ranking is also a means of world recognition and forms the public's image and trust in choosing PTKIN. Readiness to face APT will determine a satisfactory result.

In the context of quality assurance as a project of accreditation PTKIN must make preparations to face APT 3.0, which has many fundamental changes. Knowledge, understanding, document preparation, and implementation of good accreditation governance are prerequisites for obtaining an "excellent" score. A good university governor will significantly determine the accreditation scores. Incorrect preparation will cause failure to achieve the quality and value of accreditation, reputation, and public trust. That is why it is crucial to review the equilibration, assimilation, and transformation of governance processes as PTKIN's readiness to face accreditation. This paper explores and describes its readiness to accommodate the implementation of the new APT model.

This study of PTKIN's readiness for accreditation uses a mixed-method with embedded design. Quantitative data (accreditation scores) supports qualitative data (decision making) concurrently or sequentially. The data population was 58 PTKIN (17 UIN, 34 IAIN, and seven STAIN) divided into seven zones. The data sample was selected by purposive sampling by considering the type, accreditation value, and zone of the PTKIN. Presentation of data according to zone order. This research uses three techniques in collecting data, i.e.: (1) documentation study, (2) questionnaire, and (3) in-depth interviews through the Zoom Platform with the one on one interview method. Data were analyzed qualitatively and descriptively quantitative to get a picture of the readiness of accreditation for quality assurance of PTKI.

\section{Result and Discussion}

\subsection{Organizational Quality in Accreditation of PTKI}

Organizational quality in this research means the condition of the organization's vision and mission, governance, governance, leadership, and the Internal Quality Assurance System (SPMI) owned by PTKIN. This organization's quality is measured by the performance of the lecturers, its output, and output. The quality of the PTKI organization can be described as follows:

a. UIN Ar-Raniry Banda Aceh is currently accredited B. The management of PTKIN shows the best readiness for Evidence of Good Practices, Personnel Determination Documents, Evidence of Communication, Evidence of Leadership Review, Evidence of Management Systems, Management Documents, and Strategic Plan Documents (Renstra ) Institutional Development. The indicator that has the lowest level of achievement is the existence of a code of ethics institution.

b. UIN Raden Fatah Palembang has good organizational quality. The quality of this field of readiness occupies the highest compared to other fields. Fairly good readiness is shown for the indicators of Governance Documents, Evidence of Good University Governance, Management Documents, and Evidence of Guidelines Implementation, which have now reached 3 out of the expected score of 4 . The highest level of unpreparedness is shown for 
ethical institutions, evidence of leadership reviews, and the document of Institutional Development Strategic Plan.

c. UIN Walisongo Semarang has the best readiness in indicators of Short and Medium Term Development Plans (RPJPM), Governance Documents, Evidence of Implementation of Good University Governance (GUG), Strategic Planning Documents and Evidence of Good Governance Practices. The lowest readiness is in the Code of Ethics Institution. Another indicator in this PTKI has reached score 3, not far from the expected score, namely score 4.

d. UIN Antasari Banjarmasin in the organizational aspect has the best score on SPMI Documents, Management System Evidence, and Communication Evidence. However, this PTKI has the lowest readiness indicators in the GUG Evidence, Code of Ethics Institution, and Evidence of Guideline Implementation. None of the governance indicators has a score of zero.

e. IAIN Pontianak also shows quite good readiness compared to the organization. Indicators of Vision Mission, Governance and Governance, Leadership, and SPMI show a relatively even level of readiness at a score of 3 out of a maximum score of 4 . This PTKIN only has the best readiness in the Mid-Term and Long-Term Development Plans. The lowest score is on the Leadership Review Evidence.

f. UIN Maulana Malik Ibrahim Malang has the best readiness for all indicators that reach the maximum value, namely score 4 . Ownership of complete data and documents shows the readiness of PTKI, which is ready to face the APT 3.0 model. The hope of getting a superior ranking in future accreditation with the new model will undoubtedly be more comfortable to achieve. However, the existing documents need some adjustments with the new APT instrument.

g. IAIN Bone one also has the best readiness for all indicators. All indicators in the achievement of the maximum value, namely the value of four. Ownership of complete data shows the readiness of PTKI to face the APT 3.0 model. This condition is possible for this PTKI to get a excellent ranking in the new apt model in the future.

\subsection{Quality of Resources in Accreditation of PTKI}

The quality of PTKI resources is based on the status or number of variables: (1) Recent Accreditation Status, (2) Number of Study Programs, (3) Reputable Internationally Accredited Study Programs, (4) Reputable National Accredited Study Programs, (5) Number of Accredited Units International / National Reputation, (6) Excellent Accredited Study Program, (7) Accredited A Study Program, (8) Very Well Accredited Study Program, (9) Accredited Study Program B, (10) Well Accredited Study Program, (11) Program C Accredited Studies, (12) Unaccredited / Expired Study Programs, (13) Permanent Lecturers, (14) Professors, (15) Certified Lecturers, (16) Students.

The resource quality in apt is obtained through the $\mathrm{N}_{\mathrm{SA}}$ formula. If the $\mathrm{N}_{\mathrm{SA}}$ score is $\geq 3.5$, then the score for this indicator is 4 . However, if the $\mathrm{N}_{\mathrm{SA}}$ is $\leq 3.5$, then the score for this indicator is $\mathrm{N}_{\mathrm{SA}}+0.5$. Meanwhile, the $\mathrm{N}_{\mathrm{SA}}$ itself is obtained by the formula:

$$
\begin{aligned}
\mathrm{N}_{\mathrm{SA}}= & \left(4 \mathrm{XN}_{\mathrm{EXCELLENT}}+3,5 \mathrm{XN}_{\mathrm{A}}+3 \mathrm{XN}_{\mathrm{VERY}_{-} \mathrm{GOOD}}+2,5 \mathrm{X} \mathrm{N} \mathrm{N}_{\mathrm{B}}+2 \mathrm{XN}_{\mathrm{GOOD}}\right. \\
& \left.+1,5 \mathrm{X} \mathrm{N}_{\mathrm{C}}+1,5 \mathrm{X} \mathrm{N} \mathrm{N}_{\mathrm{M}}\right) / \mathrm{N}_{\mathrm{PS}}
\end{aligned}
$$


The quality condition of the institution is illustrated in Table 1.

Table 1. Accreditation Profile of BAN-PT

\begin{tabular}{|c|c|c|c|c|c|c|c|c|c|}
\hline \multirow{2}{*}{$\begin{array}{l}\text { PTKIN and the Result } \\
\text { of the Accreditation }\end{array}$} & \multirow{2}{*}{$\begin{array}{l}\text { Number of } \\
\text { Department }\end{array}$} & \multicolumn{7}{|c|}{ Accreditation } & \multirow{2}{*}{ Scor } \\
\hline & & Excellent & $\mathbf{A}$ & Veri Good & B & Good & $\mathrm{C} *)$ & Unaccredited $* *$ ) & \\
\hline UIN Banda Aceh (B) & 51 & - & 9 & - & 29 & 2 & 11 & - & 2,94 \\
\hline UIN Palembang (B) & 46 & - & 5 & - & 32 & - & 8 & 3 & 2,88 \\
\hline IAIN Pontianak (B) & 20 & - & 1 & - & 8 & - & 7 & 4 & 2,20 \\
\hline UIN Semarang (A) & 47 & - & 23 & - & 16 & 2 & 6 & - & 3,34 \\
\hline UIN Banjarmasin (B) & 36 & - & 1 & - & 31 & - & 5 & - & 2,95 \\
\hline UIN Malang (A) & 43 & - & 16 & - & 15 & - & 12 & - & 3.09 \\
\hline IAIN Bone (B) & 19 & - & 1 & - & 6 & 3 & 10 & - & 2,58 \\
\hline
\end{tabular}

*) including new department

**) including accreditation expiration

The results of data collection from the 16 variables are: (1) UIN Banda Aceh, which is accredited B, achieved a score of 2.94; (2) UIN Palembang, which is accredited B, achieved a score of 2.88; (3) IAIN Pontianak, which is accredited B, achieved a score of 2.20; (4) UIN Semarang, which is accredited A, achieved a score of 3,34; (5) UIN Banjarmasin, which is accredited B, achieved a score of 2.95; (6) UIN Malang, which is accredited A, achieved a score of 3.09 ; (7) IAIN Bone, which is accredited B, achieved a score of 2.58.

PTKIN of the IAIN type still has a few study programs that reach rank A so that in the upcoming APT 3.0, it is estimated that it can only reach a score of 2. Even UIN Antasari, IAIN Bone, and IAIN Pontianak only have one accredited study program A. UIN Semarang and UIN Malang show better results with a value above 3. UIN Palembang seems that serious effort is needed to achieve a score of 4 because only 5 out of 46 study programs are accredited A. The data is different from the international certification data held by UIN Palembang, which already has 38 study programs ISO 9001: 2015 certified. This certification was also owned by the study program at UIN Malang in 2017 but only based on academic services according to policy. UIN Malang is also in the process of AUN QA certification for several study programs. There is no PTKIN certified/accredited internationally except UIN Palembang and UIN Malang.

The data on Human Resources (SDM) shows that the lecturer ratio score is still based on the $\mathrm{R}_{\mathrm{DPS}}$ score; If the $\mathrm{R}_{\mathrm{DPS}}$ is $\geq 12$, the lecturer score will still be 4 ; If $6 \leq \mathrm{R}_{\mathrm{DPS}} \leq 12$, then the score is $\mathrm{R}_{\mathrm{DPS}} / 3$; and If the $\mathrm{R}_{\mathrm{DPS}} \leq 6$ then the tertiary institution is not accredited. The APT value is obtained through a formula.

$\mathrm{R}_{\mathrm{DPS}}: \mathrm{R}_{\mathrm{DPS}}=\mathrm{N}_{\mathrm{DT}} / \mathrm{N}_{\mathrm{PS}}$

Based on this calculation, it is known that the professors' status scores in APT are: (1) UIN Banda Aceh scores 2.35; (2) UIN Palembang won a score of 2.35; (3) IAIN Pontianak scored 2.00 ; (4) UIN Semarang won a score of 2.54; (5) UIN Banjarmasin won a score of 2.51; (6) UIN Malang achieved a score of 2.43; and (7) IAIN Bone scored 2.30. The PTKIN permanent lecturer ratio score is good enough. The lowest score is still owned by IAIN Pontianak, which is 3.02. The recapitulation of data on the quality of human resources at the PTKIN studied is illustrated in Table 2. 
Table 2. Human Resources at PTKIN

\begin{tabular}{lcccccc}
\hline Name of PTKIN & $\begin{array}{c}\text { Permanent } \\
\text { lecturer }\end{array}$ & Student & $\begin{array}{c}\text { Permanent } \\
\text { Lecturer Score }\end{array}$ & Professor & PGB & Skor GB \\
\hline UIN Banda Aceh & 613 & 23.727 & 4,00 & 16 & $2,61 \%$ & 2,35 \\
UIN Palembang & 534 & 19.325 & 3,87 & 14 & $2,62 \%$ & 2,35 \\
IAIN Pontianak & 181 & 8.367 & 3,02 & - & $0,00 \%$ & 2,00 \\
UIN Semarang & 573 & 18.980 & 4,00 & 23 & $4,01 \%$ & 2,54 \\
UIN Banjarmasin & 369 & 10.336 & 3,87 & 14 & $3,79 \%$ & 2,51 \\
UIN Malang & 589 & 18.624 & 4,00 & 19 & $3,23 \%$ & 2,43 \\
IAIN Bone & 178 & 6.325 & 3,12 & 4 & $2,25 \%$ & 2,30 \\
\hline
\end{tabular}

The lecturer ratio score is still searched based on the $R_{D P S}$ score: (1) if the $R_{D P S}$ is $\geq 12$, then the lecturer score is 4; (2) ii. if $6 \leq R_{D P S} \leq 12$, then the score is $R_{D P S} / 3$; and (3) if $R_{D P S} \leq 6$, then the university is not accredited. The ratio of professors is also taken into account for the assessment of human resources aspects with the formula:

$\mathrm{P}_{\mathrm{GB}}=\left(\mathrm{NDT}_{\mathrm{GB}} / \mathrm{N}_{\mathrm{DT}}\right) \times 100 \%$

If the $\mathrm{P}_{\mathrm{GB}}$ value $\geq 15 \%$, then the professor's score is 4 . If the score $=2+\left(\left(40 \times \mathrm{P}_{\mathrm{GB}}\right) / 3\right)$. The number of PTKIN professors is still far from ideal because it has only reached $15 \%$, so professors' need is still huge.

$\mathrm{P}_{\mathrm{GB}}=\left(\mathrm{NDT}_{\mathrm{GB}} / \mathrm{N}_{\mathrm{DT}}\right) \times 100 \%$

If the $\mathrm{P}_{\mathrm{GB}}$ value $\geq 15 \%$, then the professor's score is 4 . If the score $=2+\left(\left(40 \times \mathrm{P}_{\mathrm{GB}}\right) / 3\right)$. The number of PTKIN professors is still far from ideal because it has only reached $15 \%$, so professors' need is still huge.

\subsection{PTKI's Readiness to Face APT 3.0}

In facing the implementation of the new accreditation model, PTKIN needs to map the real conditions that have been achieved. The map of document availability stems from data on the quality of the organization and the quality of human resources that have been achieved / owned by each PTKIN as illustrated in Table 3.

Table 3. Recapitulation of PTKIN's Readiness to Face APT 3.0

\begin{tabular}{llllll}
\hline \multicolumn{1}{c}{ Indicators } & \multicolumn{5}{c}{ Skor $(\boldsymbol{f})$} \\
& $\mathbf{4}$ & $\mathbf{3}$ & $\mathbf{2}$ & $\mathbf{1}$ & $\mathbf{0}$ \\
\hline Vision and Mission & & & & & \\
$\quad$ Development Planning RPJMP & 3 & 0 & 0 & 0 \\
Governance & & & & & \\
$\quad$ Governance Document & 3 & 4 & 0 & 0 & 0 \\
$\quad$ Evidence of GUG & 3 & 3 & 1 & 0 & 0 \\
$\quad$ Code of Ethics Institution & 2 & 1 & 3 & 0 & 1 \\
Leadership & & & & & \\
$\quad$ Document on Personal Determination & 3 & 3 & 1 & 0 & 0 \\
$\quad$ Evidence of Communication & 4 & 2 & 0 & 1 & 0 \\
$\quad$ Evidence of Leadership Review & 3 & 2 & 1 & 0 & 1 \\
Management & & & & & \\
$\quad$ Management System Evidence & 4 & 2 & 0 & 1 & 0 \\
\hline
\end{tabular}




\begin{tabular}{llllll}
\hline Indicators & \multicolumn{4}{c}{ Skor $(\boldsymbol{f})$} \\
& $\mathbf{4}$ & $\mathbf{3}$ & $\mathbf{2}$ & $\mathbf{1}$ & $\mathbf{0}$ \\
\hline Management Document & 3 & 3 & 1 & 0 & 0 \\
Evidence of Guidelines Implementation & 2 & 3 & 2 & 0 & 0 \\
Strategic Plan Document & 4 & 2 & 0 & 1 & 0 \\
Quality Assurance System & & & & & \\
Document of Internal Quality Assurance (SPMI) & 4 & 3 & 0 & 0 & 0 \\
Evident of Goof Practices & 4 & 2 & 1 & 0 & 0 \\
\hline
\end{tabular}

Based on the table, four PTKINs have owned the vision and mission aspects with a score of 4. This condition is very potential still to achieve a score of 4 in the next accreditation. Other PTKINs achieved a score of 3 . The PTKIN of this group is quite prepared to reach a 4 in the next APT if they made improvements. In the aspect of Governance and Governance, the best score is shown by the Governance Document indicator. A score of 4 for this indicator went to three PTKINs and a score of 3 to four PTKIs. The lowest readiness (score 2) is in the Code of Ethics Institution indicator, which is still owned by most PTKIN. Six PTKINs already have this institution but have not yet maintained integrity consistently, effectively, and efficiently. There are also PTKIN, which do not have a code of ethics institution.

In the Leadership Aspect, the Document of Personnel Determination indicator is the best readiness in facing accreditation. Two PTKINs achieved a score of 4, 3 PTKIN (score 3), and one PTKIN (score 2). The lowest readiness occurs in the Leadership Review Evidence indicator, which still shows 0 (zero) score on one PTKI, even though there are already 3 PTKINs that have achieved a score of 3 . This condition still requires serious preparation to be able to achieve an excellent predicate in APT 3.0. This aspect of leadership requires serious readiness so that it can give support to other aspects.

While the management aspects of PTKIN show different conditions, many PTKINs have ready achieved the best accreditation score of 4 and 3 on the Strategic Plan Document indicator. They refer to the PTKIN's Vision, Mission, Goals, and Targets as well as the existence of international benchmarks. PTKIN already has evidence on planning, organizing, personnel placement, direction, and supervision. However, other PTKINs showed the lowest levels of unpreparedness. There is PTKIN, whose Strategic Plan document and has no robust evidence of good management.

The quality assurance system in PTKIN also has satisfactory readiness. The majority of PTKIN has achieved a score of 4 . The implementation of SPMI is shown by complete documents and evidence of follow-up and has a standard that exceeds the national higher education standards and implements a risk-based SPMI. However, there is PTKIN achieved a score of 2 in the accreditation. The PTKIN does not have valid evidence regarding acceptable practices in developing a quality culture through management review meetings. This meeting will discuss the results of internal audits, feedback, process performance and product suitability, preventive and corrective actions, a follow-up to previous reviews, and changes that can affect the quality management system. This meeting also produced recommendations for quality improvement.

\section{Conclusion}

Based on the aspects of the value of accreditation, organization, and human resources, there is no PTKIN that is truly ready to face APT 3.0. The level of readiness of each PTKIN in facing APT is not equal. Only $28.6 \%$ (two out of seven) PTKIN has a sound management 
system and internal quality assurance system in organizational quality. The acquisition of a study program accreditation score above 3.0 will support the readiness of the organization's quality aspects for future accreditation. Achievement of A scores on Study Program Accreditation is also still low. Only 56 of the 262 (21.3\%) Study Programs at PTKIN have obtained an $\mathrm{A}$ in their accreditation.

In terms of the quality of human resources, the PTKIN permanent lecturer ratio score is quite good. 42.8\% (three out of seven) PTKIN studied had obtained the highest score (score 4) in their accreditation. However, the number of professors to the number of lecturers is still very far from expectations; PTKIN owns only 2.96\% (90 out of 3037) of permanent lecturers. The number of PTKIN professors is still far from ideal. The need for an increase in the number of professors is needed to improve future APT scores' quality and achievement.

PTKIN still needs serious work to deal with the new APT model so that the results are satisfactory. These findings are beneficial for stakeholders as a basis for determining policies and decisions to prepare the needs for accreditation and quality assurance of PTKIN. The leadership of PTKIN and the Ministry of Religion need to make particular policies to face APT 3.0 to achieve the title of excellence and increase global trust and recognition.

\section{Acknowledgments}

This paper comes from research funded by the Operational Support State University (BOPTN) at the Institute for Research and Community Service (LP2M), Universitas Islam negeri Walisongo Semarang, Indonesia, Fiscal Year 2020.

\section{References}

[1] Ibrahim, Hassan Al-Haj. "Quality Assurance and Accreditation in Education"., Open Journal of Education 2, no. 2 (2014): 106-110. https://doi.org/10.12966/oje.06.06.2014.

[2] Komotar, Maruša Hauptman. "Discourses on Quality and Quality Assurance in Higher Education from the Perspective of Global University Rankings"." Quality Assurance in Education 28, no. 1 (2020): 78-88. https://doi.org/10.1108/QAE-05-2019-0055.

[3] Mourad, M. "Students' Perception of Quality Assurance Activities: Case Study from the European Higher Education Market"." Sustainability Accounting, Management and Policy Journal 4, no. 3 (2013): 345-365. https://doi.org/10.1108/SAMPJ-01-20130007.

[4] Nguyen, Huu Cuong, Colin Evers, and Stephen Marshall. “Accreditation of Viet Nam's Higher Education: Achievements and Challenges after a Dozen Years of Development"." Quality Assurance in Education 25, no. ue: 4 (2017): 475-488,. https://doi.org/10.1108/QAE-11-2016-007.

[5] "Peraturan BAN-PT Nomor 2 Tentang Sistem Akreditasi Nasional Pendidikan Tinggi," 2017.

[6] "Peraturan BAN-PT Nomor 4 Tahun 2017 Tentang Kebijakan Penyusunan Instrumen Akreditasi," 2017.

[7] Piaget, Jean. "The Development of Thought: Equilibration of Cognitive Structures, Tran Arnold Rosin.” New York: Viking Press, 1977.

[8] Schomaker, Rahel. "Accreditation and Quality Assurance in the Egyptian Higher Education System"." Quality Assurance in Education 23, no. 2 (2015): 149-165. 
https://doi.org/10.1108/QAE-08-2013-0034. 